\title{
A Study on the Chronological Changes and Their Short-Lived Effects on the Market Index and the Stock Return of Tehran Stock Exchange Market
}

\author{
Farhad Hanifi $^{1}$, Hamid Mahdavirad ${ }^{2}$, Hamidreza Kordlouie ${ }^{3}$ \\ ${ }^{1}$ Business Department, Tehran Branch of Islamic Azad University, Tehran, Iran \\ ${ }^{2}$ Business Department, Islamic Azad University, Malayer, Iran \\ ${ }^{3}$ Finance Department, Islamic Azad University, Islamshahr, Iran \\ Correspondence: Hamidreza Kordlouie, Finance Department, Islamic Azad University, Islamshahr, Iran.
}

Received: November 5, 2014

Accepted: November 20, 2014

Available online: January 5, 2015

doi:10.11114/afa.v1i1.577

URL: http://dx.doi.org/10.11114/afa.v1i1.577

\begin{abstract}
Detection and prediction of return fluctuations of securities have always been of great interest to those active in financial markets, leading to their research in financial and economic fields. This research aims at studying and detecting the return difference on specific days and months of a given year-if there is any. For this research the 2 lunar months of Ramadan and Muharram along with the two solar months of Farvardin- March 21 to April 2- and Shahrivar August 22 to September 22 were chosen. In order to carry out this research, the return difference of the afore-mentioned months was tested against those of other months. Moreover, the return difference of a specific day of the week, namely Saturday - the beginning day of the week in Iran- was also tested against that of the other weekdays. It should be mentioned that the research also aimed at studying the difference of the aforementioned months and days with reference to the principles of behavioral finance. The research considered a 13 year span of time- from 2001 to 2013. Generally speaking, the following research studies the level of effect of chronological changes on a set of target indexes in Tehran securities market in the pre-mentioned span of time. The statistical method applied for the research is thesign test. The results of this research proved significant differences in the return patterns of the target months; however, these differences did not prove to be meaningful in any way.
\end{abstract}

Keywords: behavioral finance, return, index, chronological effects, sign test.

\section{Introduction}

Investment has always been intertwined with decision making. As a matter of fact, these two concepts always go hand in hand with each other. Decisions for investment are always based on the investor's insight. Nowadays, finance considers two types of insight for investors' decisions: the purely logical and behaviorally motivated decisions. The former type believes that all of the investor's decisions are made purely rationally. This "Classical" view builds all models of determining the substantial value of assets on this presupposition. The behavioral finance, on the other hand, challenges the belief of total rationality of the investors, claiming the existence of other sources of effect on the decisions of the investors which are not necessarily rational. In literature of finance, this view is named "the behaviorist finance". This new perspective incorporates such sciences as psychology and anthropology. Macro and Micro behaviorist finance are the two major branches of behaviorist finance - BF. Micro BF deals with the tendencies and inclinations of the investors at a personal level, while the Macro BF deals with these at the public -social level.

As a matter of fact, the current research does also target the study of the amount of the effects the chronological along with the calendar time changes can have on a set of target indexes so to determine its effectiveness in Tehran stock market. Recently, many researches has been carried out all over the world on this issue. Most of these researches look for the amount of the effect the New Year holidays- known as the January effect- can have on the price and return of the stock market shares. The current research studies the effect of the 2 lunar-calendar months of Ramadan and Moharram along with the two solar-calendar months of Farvardin and Shahrivar as well as Saturdays - the first day of the week in Iran- as compared to those of other months and days on the return of the stocks. A separate hypothesis can be developed for each of these week days. It should be mentioned that the target return for the current research is considered for 7 differing index bases - top 50 companies, industry, finance, General total, car manufacturers, cement factories, and multi- field industries. For example, for the lunar month of Moharram, 7 differing returns were estimated to be ,finally , 
compared to that of other lunar monthsin the span of 2001-2014.

\subsection{Review of the Related Literature}

Research in this area can be divided into 2 main categories of researches in developed countries' markets and research in developing countries' markets. The current research focuses on the issue of the chronological events - especially those Islamic occasions such as Ramadan- on the financial markets.

The first study on the effect of days of the week on the US stock market was carried out by Fields (1931). He studied the common logic in Wall Street, stating that those active in the stock exchange market worry less during the last days of the week. Therefore, they prefer to transform them into other forms of assets, leading to a cut in the price of the securities on Saturdays. He tested the Dow Jones from 1915 to 1930 so to test the validity of the a.m. common belief. He found out that the prices tend to increase on Saturdays.

Cross (1973) studied the return of S\&P 500 index from 1952 to 1970 . He found out that the index increased on $62 \%$ of Fridays. The average return on Fridays was 12 , while on Mondays it was $18 \%$.

Berument and Kiymaz (2001) studied about the presence of the day of the week effect on stock market volatility by using the S\&P 500 market index. They found out the day of the week effect is present in both volatility and return equations. Meanwhile the highest and lowest returns are observed on Wednesday and Monday, the highest and the lowest volatility are observed on Friday and Wednesday, respectively.

French (1980) did also study the same S\&P 500 from 1953 to 1977 to compare the daily returns and to make similar results. He came up with the hypothesis of trading time. According to this hypothesis, return is formed only on the week days, being the same on normal days of stock exchange. An alternative to this hypothesis, the calendar time hypothesis, states that the returns are also formed on the non-working days of the week.

According to the calendar time hypothesis, the prices need to be little higher on Mondays than other week days because there is a three-day span between the Friday as the last day of the working week and Monday as the beginning of the new week while for the normal week days this span of time is just one day. He tested these two hypotheses over a 25-year period. being divided into 5, five-year sub-periods, He found out that the average return for Mondays is negative, while it is positive for other days of the week, with Fridays and Wednesdays having the highest positive return. In this way, both hypotheses proved to be rejected.

He also came up with the idea that due to some unclear factors related to the closed markets, the expected return had to be less on weekends as opposed to the weekdays. Contrary to his pre-supposition, French found out that the average return was higher on Mondays, Wednesdays, Thursdays, and Fridays which happen after a holiday. Moreover, on Tuesdays that happen after a holiday, the return would be negative.This negative return would be attributed to the result of the delay of the markets' opening. He concluded his findings as a sign of the existence of something on the weekend to be negatively correlated to the market's closing.

Cooper et al. (2006) surveyd the predictive power of January returns they find that January returns have predictive power for market returns. They also find that January has predictive power for two of the three premiums in the Fama - French three-factor model of asset pricing.

Eilers et al. (2014) present a decision support algorithm which uses the powerful ideas of reinforcement learning in order to improve the economic benefits of the basic seasonality strategy. Research team document the performance on two major stock indices.

Gibbsons and Hess (1981), studied the effect of the days of the week on S\&P 500 index from 1962 to 1978 which was based on the data provided by the center for research on the price of securities. In order to find out if their findings would conform to the circumstance on the weekends, they paid attention to the effects of the weekdays on treasury notes. They finally got to understand that the average return of Mondays was significantly lower than the other days.

Reinganum (1983) indicates abnormally high returns witnessed at the very beginning of January. He also confirms that, tax-loss selling cannot explain the entire January seasonal effect. meanwhile small firms least likely to be sold for tax reasons (prior year 'winners' ) also exhibit large average January returns, although not unusually large returns during the first few days of January.

\subsection{Behavioral Finance and the Market Return}

Under normal circumstances in financial markets there are always those with redundant resources and those who lack such resources. In this way, the redundant funds would find their way into those entities that lack resources. The major challenge for the investors and suppliers, in these markets, is to make the maximum return from their own redundant funds. Meanwhile, those entities that attract such funds challenge to utilize these funds efficiently and effectively. 
Market considers some level of risk for each of these entities according to the nature of their activities and the volume of the venture they carry out. Meanwhile, both of these groups make decisions on the way to achieve their goals. As a matter of fact, behavioral finance studies the human factors affecting such decisions to find out the extent of the rationality of the decisions. New research emphasizes the role of such human emotions as fear, hatred, philanthropy, and conscience on the behaviors of the people in financial markets. In other words, people make decisions on an axiom of decisions, running from the extremely emotional decisions to extremely rational ones; however, rationality is not an absolute concept, and one cannot expect a purely rational decision without the effect of human factors.

From amongst the many definitions proposed for an efficient market, the most comprehensive one defines an efficient market to be, "a market where the prices react to the release of the information immediately, moving towards the real value of the goods." As a matter of fact, the redundant return in this market - that portion of the return that cannot be attributed to the total changes in the market- equals zero in an efficient market. Under exceptional circumstances, as a result of the positive gain on the part of the redundant return, some changes happen in the market to make this return zero again.

In an efficient market the daily pricesare not related to the price changes in the past, and the technical analyses are of no use in it because all assets exist in their fundamental value, leading to a decrease in the chances of arbitrage.

Three factors affect the efficiency in the markets:

\subsubsection{The Speed of the Flow of Information}

The faster the speed of the flow of the information towards the public , the faster the prices react, moving towards their substantial value. As soon as something new happens, everybody gets informed. Then the market mechanisms carry out an estimation of the fundamental value. On the contrary, if the information is not publicized quickly, and if some people get the news earlier than the others, it provides them with an unjust opportunity and jeopardizes market efficiency.

\subsubsection{The Volume of the Exposed Information}

The amount of the available information useful for making decisions is an important factor in determining the efficiency level of the market. In a perfectly efficient market, all the information needed to making decisions for buying or selling such asset as stocks is useful for all the people active in markets .

\subsubsection{The Content and the Quality of the Exposed Information}

Quality information in the markets functions as the navigator to the real value of the assets. This is an important factor in determining the function of the markets. In this case, too, the balance between the information's being on-time and its reliability is a major, on-going challenge of the people active in the markets.

In an efficient market, the risk taking quality of the market is linearly and positively correlated with the return of the market. Anyway, the market return is relative and no market is fully efficient, facing the people active in the markets with various levels of efficiency in the market.

\subsection{Market Anomies}

Always there are anomies in the market .these anomies take the return of the market under question. The current research studies the consequences and the effects of some of such anomies from the perspective of behavioral finance.

In the price trend of the assets - esp. stocks- there are two types of anomies taking place. These anomies do not follow the fundamental and technical principles of valuing the stocks. These two anomies are:

\section{1- Calendar anomie}

\section{2- Non-calendar anomie}

The effect of the cheap stocks on the more expensive stocks (cheap stocks provide much better returns) or the publication of pre-emption is samples of non-calendar changes. The January effect or the summer effects , however, are two examples of the calendar anomies.

As can be seen, the aforementioned cases cannot be justified on the grounds of rational, economic, or financial justifications. Behavioral finance studies these anomies in an attempt to justify and explain them, applying the principles of human behavior. It , however, does not pave the way to get around with the application of the fundamental concepts of economics.

The current paper studies some of the non-calendar anomies in relation to the current circumstances in Iran. This research is carried out within the realm of behavioral finance; moreover, practical work was also carried out, using econometrics. Some time series models such as ARCH and GARCH were applied to detect and observe the trend of the return within the target time spans. 


\section{Methodology}

Sing test was used as the statistical method for this research. This method is applied to detect the differences of a sign under two different circumstances. This test is devised for correlated variables; however, there is no need for the variables to follow normal distribution or to have been extracted from the same population. It is therefore that this model is a very flexible model. In this method, the findings are being studied in pairs - from the two respective circumstances in order for each pair to be allocated with a minus or plus sign. The null hypothesis for this study means no difference between the two circumstances; in other words, almost half of the studied pairs would be plus and the other half would be minus. It should also be mentioned that the lack of this balance is a representation of the difference between the two circumstances under study.

Nullhypothesis to be tested through the sign test is as follows:

$$
\mathrm{P}\left(\mathrm{X}_{\mathrm{A}}>\mathrm{X}_{\mathrm{B}}\right)=\mathrm{P}\left(\mathrm{X}_{\mathrm{A}}<\mathrm{X}_{\mathrm{B}}\right)=\frac{1}{2}
$$

Where $X_{A}$ the judgment or the score is allocated for one of the circumstances and $X_{B}$ is the score or the judgment allocated for the other circumstance. Another way to present the null hypothesis is to state that the median of the differences equals zero.

It should be mentioned that the data for the current study was also tested through Friedman's statistical test.

For each of the 14 years under study, 7 various spans based on 7 differing indexes were calculated - the total price, financial, industry, top 50 companies, automotive industries, cement industries, and multi-discipline industries.

The returns were also calculated two times; once for each of the circumstances under study - Mohharram, Ramadan, Farvardin, and etc.) and once under normal circumstances. Finally the findings were compared.

\subsection{Research hypotheses}

2.1.1 There is a meaningful difference between the market return of the market in the sacred month of Ramadan and the other months.

2.1.2 There is a meaningful difference between the market return in the month of Ramadan and the other months.

2.1.3 There is a meaningful difference between the market return in the month of Farvardin and the other months.

2.1.4 There is a meaningful difference between the market return in the month of Shahrivar and the other months.

2.1.5 There is a meaningful difference between the market return on tuesdays and the other days of the week.

\subsection{Duration and Location of the research}

The research studies a span of time between 2001 to 2014. The target data for the research was collected from the companies understudy in this period.

As an example, take the example of the month of Farvardin - 21 march to 22 April- 2003 , for-which 7 differing returns were calculated to be compared to the normal return in the future. Finally, as a result of the study of all of the target years, the existence of the difference in the return of Farvardin (around April) as opposed to all other months of the year can be decided upon. It should be mentioned that all the comparisons were carried out by the sign test,.

The reason for choosing the 3 industries of cement, automobile, and the multi-disciplinary sectors was the fact that these sectors had the highest value in the market during the period of time of the research.

The research was subject to some limitations that had their roots back in the lack of the information on the indexes under study- in order for the researcher to apply the formula to calculate the return per index, the index value in the beginning and the end of the research span of the time was needed. It should be mentioned that the research was a descriptive research with a practical approach.

\section{Data Analysis}

The data required for the pioneer research was gathered based on the variables developed as a result of forming the research hypotheses. As stated before, the research aims at finding out the difference between the return of the stock exchange market at specific periods of time as compared to other times. It is therefore that of the researchers had to calculated the return for two lunar and two solar months ${ }^{1}$ along with one day of the week. However, in order to do

\footnotetext{
1 The Iranian calendar, the Jalali calendar, is a solar calendar ;however, as opposed to the Georgian calendar, it has the travel of the prophet Mohammad from Mecca to Madina as its starting date. It should be mentioned that almost all other Muslims use the lunar
} 
so, just the fluctuations of 4 indexes namely the aggregation index, financial index, industrial index , and the top 50 companies' indexes were gathered. Later, based on this data, the return of each of the a.m. indexes was calculated for the target span of time. In addition, the return of the top three industrial sectors-with the highest return in the stock exchange market- was also incorporated into the research from the reports of the boards of the directors to the A.G.M.

The top three industries with the highest return in the stock exchange market include the automotive industries , cement industries, and conglomerate industries. Later, based on the fluctuations of the indexes of the industries with the highest market value, the market return was calculated for each of the target periods of times to be compared to the returns of the same industries over other periods of time. Therefore, there were 7 return values for each year. These return values were calculated based on the following formula:

$$
R=100 \log \left(\frac{\mathrm{Ix}}{\mathrm{Ix}_{-1}}\right)
$$

Where $\mathrm{Ix}$ is the end of the period index and $\mathrm{Ix}_{-1}$ is the beginning of the period index. $\mathrm{R}$ is also the return.

Table 1. The Month of Moharram Sign Test for the 7 Indexes

\begin{tabular}{|c|c|c|c|c|c|}
\hline Index name & $\begin{array}{l}\text { the return of } \\
\text { those lunar } \\
\text { months that are } \\
\text { less than the } \\
\text { month of } \\
\text { Ramadan }\end{array}$ & $\begin{array}{l}\text { return of those lunar } \\
\text { months whose return } \\
\text { were bigger than that of } \\
\text { the month of Ramadan }\end{array}$ & $\begin{array}{l}\text { return of those lunar } \\
\text { months whose returns } \\
\text { were equal to that of the } \\
\text { month of Ramadan }\end{array}$ & $\begin{array}{l}\text { The total number } \\
\text { of the years } \\
\text { under study }\end{array}$ & $\begin{array}{l}\text { The level of } \\
\text { meaningfulness }\end{array}$ \\
\hline Price index & 6 years & 2years & - & 13 & $72 \%$ \\
\hline Financial index & 3 years & 5 years & - & 13 & $28 \%$ \\
\hline Industries index & 5 years & 3 years & - & 13 & $28 \%$ \\
\hline $\begin{array}{l}\text { Top } 50 \\
\text { companies' index }\end{array}$ & 4years & 3 years & - & 11 & 0 \\
\hline $\begin{array}{l}\text { Automotive } \\
\text { industry index }\end{array}$ & 2years & 4 years & - & 10 & $32 \%$ \\
\hline $\begin{array}{l}\text { index industry } \\
\text { cement }\end{array}$ & 3 years & 1 year & - & 8 & $38 \%$ \\
\hline $\begin{array}{l}\text { conglomerate } \\
\text { industries }\end{array}$ & 4 years & 0 year & - & 8 & $88 \%$ \\
\hline
\end{tabular}

Table 2. The Month of Moharram Sign Test for the 7 Indexes

\begin{tabular}{|c|c|c|c|c|c|}
\hline Index name & $\begin{array}{l}\text { The average return of } \\
\text { those lunar months } \\
\text { whose returns were } \\
\text { smaller than that of } \\
\text { the month of } \\
\text { Ramadan }\end{array}$ & $\begin{array}{l}\text { The average return of } \\
\text { those lunar months } \\
\text { whose return were } \\
\text { bigger than that of the } \\
\text { month of Ramadan }\end{array}$ & $\begin{array}{l}\text { those lunar months } \\
\text { whose returns were } \\
\text { equal to that of the } \\
\text { month of Ramadan }\end{array}$ & $\begin{array}{l}\text { The total number } \\
\text { of the years under } \\
\text { study }\end{array}$ & $\begin{array}{l}\text { The level of } \\
\text { meaningfulness }\end{array}$ \\
\hline total price index & 3 years & 5 years & - & 13 & $28 \%$ \\
\hline financial index & 3 years & 5 years & - & 13 & $28 \%$ \\
\hline industries index & 3 years & 5 years & - & 13 & $28 \%$ \\
\hline $\begin{array}{l}\text { Top } 50 \text { companies' } \\
\text { index }\end{array}$ & 3 years & 4 years & - & 11 & $28 \%$ \\
\hline $\begin{array}{l}\text { automative } \\
\text { industries index }\end{array}$ & 3 years & 3 years & - & 10 & $28 \%$ \\
\hline $\begin{array}{l}\text { Cement industry's } \\
\text { index }\end{array}$ & 3 years & 1 year & - & 8 & $38 \%$ \\
\hline $\begin{array}{l}\text { conglomerate } \\
\text { industry s index }\end{array}$ & 3 years & 1 year & - & 9 & $38 \%$ \\
\hline
\end{tabular}

calendar instead. However, both these calendars have the occasion of prophet Mohammad's travel to Madina as their time origination. 
Table 3. The Month of Farvardin (March 21 to April 22) Sign Test for the 7 Indexes

\begin{tabular}{|c|c|c|c|c|c|}
\hline Index name & $\begin{array}{l}\text { The average number of } \\
\text { those solar months } \\
\text { whose returns were } \\
\text { smaller than that of the } \\
\text { month of Ramadan }\end{array}$ & $\begin{array}{l}\text { The average number } \\
\text { of those solar months } \\
\text { whose returns were } \\
\text { bigger than that of } \\
\text { the month of Ramadan }\end{array}$ & $\begin{array}{l}\text { The average number } \\
\text { of those solar } \\
\text { months whose } \\
\text { returns were equal } \\
\text { to that of the month } \\
\text { of Ramadan }\end{array}$ & $\begin{array}{l}\text { Number of the } \\
\text { years under study }\end{array}$ & $\begin{array}{l}\text { Level of } \\
\text { meaningfulness }\end{array}$ \\
\hline $\begin{array}{l}\text { total price } \\
\text { index }\end{array}$ & 5 years & 3 years & - & 13 & $28 \%$ \\
\hline finacial index & 4 years & 4 years & - & 13 & 0 \\
\hline industrial index & 7 years & 1 year & - & 13 & $93 \%$ \\
\hline $\begin{array}{l}\text { fifty top } \\
\text { companies index }\end{array}$ & 8 years & 0 year & - & 13 & $99 \%$ \\
\hline $\begin{array}{l}\text { automative } \\
\text { industry index }\end{array}$ & 7 years & 1 year & - & 13 & $93 \%$ \\
\hline $\begin{array}{l}\text { cement industry } \\
\text { index }\end{array}$ & 3 years & 1 year & - & 9 & $38 \%$ \\
\hline $\begin{array}{l}\text { conglomerate } \\
\text { industry s index }\end{array}$ & 3 years & 1 year & - & 8 & $38 \%$ \\
\hline
\end{tabular}

Table 4. The Month of Shahrivar( September 11 to October 12) Sign Test for the 7 Indexes

\begin{tabular}{|c|c|c|c|c|c|}
\hline index name & $\begin{array}{l}\text { The average } \\
\text { number of those } \\
\text { solar months } \\
\text { whose returns were } \\
\text { smaller than that of } \\
\text { the month of } \\
\text { Ramadan }\end{array}$ & $\begin{array}{l}\text { The average number } \\
\text { of those solar } \\
\text { months whose } \\
\text { returns were bigger } \\
\text { than that of the } \\
\text { month of Ramadan }\end{array}$ & $\begin{array}{l}\text { The average } \\
\text { number of those } \\
\text { solar months } \\
\text { whose returns } \\
\text { were equal to that } \\
\text { of the month of } \\
\text { Ramadan }\end{array}$ & $\begin{array}{l}\text { Number of the } \\
\text { years under } \\
\text { study }\end{array}$ & $\begin{array}{r}\text { Level of } \\
\text { meaningfulness }\end{array}$ \\
\hline total price index & 2years & 6 years & - & 13 & $72 \%$ \\
\hline financial index & 4 years & 4 years & - & 13 & 0 \\
\hline industres index & 3 years & 5 years & - & 13 & $28 \%$ \\
\hline $\begin{array}{l}\text { top fifty } \\
\text { companies index }\end{array}$ & 3 years & 5 years & - & 13 & $28 \%$ \\
\hline $\begin{array}{l}\text { automative } \\
\text { industry index }\end{array}$ & 2 years & 6 years & - & 13 & $72 \%$ \\
\hline $\begin{array}{l}\text { cement industry } \\
\text { index }\end{array}$ & 2 years & 2years & - & 8 & 0 \\
\hline $\begin{array}{l}\text { conglomerate } \\
\text { industry s index }\end{array}$ & 3 years & 1 year & - & 8 & $38 \%$ \\
\hline
\end{tabular}

Table 5. The Days of the Week Sign Test for the 7 Indexes

\begin{tabular}{|c|c|c|c|c|c|}
\hline index name & $\begin{array}{l}\text { Average number of } \\
\text { the weekdays with } \\
\text { the smaller than } \\
\text { Saturday index }\end{array}$ & $\begin{array}{l}\text { Average number of } \\
\text { the weekdays with } \\
\text { bigger than } \\
\text { Saturday index }\end{array}$ & $\begin{array}{l}\text { Average number } \\
\text { of the weekdays } \\
\text { with a return } \\
\text { equal to that of } \\
\text { saturday index }\end{array}$ & $\begin{array}{l}\text { total number of } \\
\text { the years under } \\
\text { study }\end{array}$ & $\begin{array}{l}\text { level of } \\
\text { meaningfulness }\end{array}$ \\
\hline total priceindex & 6 years & 2years & - & 13 & $72 \%$ \\
\hline financial index & 6 years & 5 years & - & 13 & $30 \%$ \\
\hline industries index & 7 years & 1 year & - & 13 & $93 \%$ \\
\hline $\begin{array}{l}\text { top } 50 \text { companies } \\
\text { index }\end{array}$ & 6 years & 1 year & - & 11 & $88 \%$ \\
\hline $\begin{array}{l}\text { automative } \\
\text { industry index }\end{array}$ & 5 years & 2 years & - & 11 & $45 \%$ \\
\hline $\begin{array}{l}\text { cement industry } \\
\text { index }\end{array}$ & 1 year & 4 years & - & 10 & $38 \%$ \\
\hline $\begin{array}{l}\text { conglomerate } \\
\text { industry s index }\end{array}$ & 3 years & 1 year & - & 9 & $38 \%$ \\
\hline
\end{tabular}


Table 6. Fridman Test Analysis of the Lunar Calendar Months for the 7 Indexes

\begin{tabular}{|c|c|c|c|c|c|c|c|c|c|c|c|c|c|}
\hline Index & Moharam & Safay & Rabi-olarval & Rabicosari & Jamadiohwral & Jamidiossani & Rajab & Shib an & Ramathan & Sharal & Zihaje & Zighade & $\mathrm{Sig}$ \\
\hline total price & 625 & $7 / 63$ & 7138 & 700 & 800 & $4 / 63$ & $5 / 38$ & 700 & 813 & 663 & 5,18 & $4 / 13$ & $\% 88$ \\
\hline intustries & 650 & $7 / 63$ & 675 & 675 & 725 & $4 / 38$ & $5 / 63$ & 608 & 900 & 700 & $6 / 25$ & 4,00 & $\% 67$ \\
\hline top fifty conquaries & 5.64 & 600 & 800 & $7 / 64$ & $8 \pi 1$ & $4 / 51$ & $5 / 43$ & 743 & 657 & 5157 & & & $\% 45$ \\
\hline finarcial & 700 & 825 & 788 & 738 & 750 & $5 / 25$ & 4775 & 758 & 6.00 & 600 & 500 & 5163 & $\% / 44$ \\
\hline automative & $7 n 7$ & 717 & $9 / 17$ & 800 & 650 & 517 & 5133 & 300 & 550 & 650 & $7 / 50$ & 700 & $\% 0$ \\
\hline cemert & 788 & 500 & 613 & 738 & 788 & 225 & $5 / 50$ & 875 & 675 & 600 & $6 / 25$ & 825 & $\% 54$ \\
\hline $\begin{array}{l}\text { conglomenate } \\
\text { xindus tys inde }\end{array}$ & 8113 & $3 / 50$ & 813 & 900 & 725 & 600 & $4 / 50$ & 725 & $8 B 8$ & $3 / 50$ & 6188 & 5150 & $\% / 66$ \\
\hline
\end{tabular}

Table 7. Fridman Test Analysis for the Return of Solar Calendar Months for the 7 Indexes

\begin{tabular}{|c|c|c|c|c|c|c|c|c|c|c|c|c|c|}
\hline Month & Month 1 & Month 2 & Month 3 & Month 4 & Month 5 & Month 6 & Month 7 & Month 8 & Month 9 & Month 10 & Month 11 & Month 12 & Sig \\
\hline cost price & 8.13 & 7.63 & 8.00 & 7.25 & 5.75 & 6.00 & 3.88 & 6.13 & 7.00 & 7.88 & 5.00 & 5.38 & $68 \%$ \\
\hline industries & 8.75 & 7.50 & 7.88 & 7.50 & 4.63 & 6.50 & 4.38 & 6.88 & 7.63 & 6.88 & 4.25 & 5.25 & $71 \%$ \\
\hline $\begin{array}{l}\text { top fifty } \\
\text { companies }\end{array}$ & 9.50 & 7.75 & 7.50 & 7.44 & 5.31 & 5.81 & 3.75 & 6.88 & 8.25 & 7.38 & 4.38 & & $84 \%$ \\
\hline automative & 9.25 & 7.75 & 7.13 & 6.25 & 2.63 & 4.63 & 5.25 & 6.75 & 7.13 & 7.25 & 6.38 & 7.63 & $95 \%$ \\
\hline cement & 9.00 & 8.25 & 5.25 & 5.25 & 4.75 & 7.50 & 7.75 & 4.25 & 8.25 & 8.00 & 6.25 & 3.50 & $61 \%$ \\
\hline $\begin{array}{l}\text { conglomerate } \\
\text { industry s index }\end{array}$ & 7.75 & 9.25 & 9.00 & 8.00 & 1.75 & 10.25 & 7.50 & 3.75 & 5.50 & 4.75 & 4.75 & 5.75 & $98 \%$ \\
\hline
\end{tabular}

\section{Discussion}

Behavioral finance is a new branch of finance. This research has been carried out according to this new discipline. The current research aimed at the studying the effect of calendar time variables on the return of Tehran Stock Exchange market. The effect of specific months and days entail a portion of the capital market anomies. In order to carry out the research two sign test models along with the Fridman test was used to evaluate the hypotheses.

As can be seen in the tables, according to the sign test, the return differences for the target months with the other months are true. It is true for the first day of the week, too. However, this difference is not significant - minimum $95 \%$. The results of the sign test shows significant return difference among the month of Farvardin - March 21 to April 22- and other months of the solar year. Generally speaking, it seems that special occasions and months show no significant effect on the return fluctuations of Tehran Stock Exchange Market.

\section{References}

Berument. H., \& Kiymaz, H. (2001). The Day of the Week Effect on Stock Market Volatility. Journal of Economics and Finance, 25(2), 181-193.http://dx.doi.org/10.1007/BF02744521

Bildik, R. (2004). Are Calendar Anomalies still alive? Evidence from Istanbul Stock Exchange. 11th Conference of the Multinational Finance Society, Montreal.

Chakrabarti, G., \& Sen, C. (2008). An Example of Calendar Anomaly in Indian Stock Market, working paper, Presidency College, Kolkata.

Cooper, M. J., McConnell, J. J., \& Ovtchinnikov, A. V. (2006). The other January effect. Journal of Financial Economics, 82(2), 315-34. http://dx.doi.org/10.1016/j.jfineco.2006.03.0011

Cross, F. (1973). The Behavior of Stock Prices on Fridays and Mondays. Financial Analysts Journal, $29,67-69$. http://dx.doi.org/10.2469/faj.

Eilers, D., Dunis, C. L., Mettenheim, H., \& Breitner, M. H. (2014). Intelligent trading of seasonal effects: A decision support algorithm based on reinforcement learning. Decision Support Systems, 64, 100-108.

Fields, M. (1931). Stock prices: a problem in verification. Journal of Business, 7, 415-418.

French, K. R. (1980). Stock returns and the weekend effect. Journal of Financial Economics, 8, 55-69. http://dx.doi.org/10.1016/0304-405X(80)90021-5. 
Gibbons, M., \& Hess, P. (1981). Day of the Week Effects and Asset Returns. Journal of Business, 54, 579-596. http://dx.doi.org/10.1086/296147.

Maghayereh, A. (2003). Seasonality and January Effect Anomalies in an Emerging Capital Markets. The Arab Bank Review, 5(2), 25-32.

Reinganum, M. R. (1983). The anomalous stock market behavior of small firms in January: Empirical tests for tax-loss selling effects. Journal of Financial Economics, 12(1), 89-104.

Wong, K. A., \& Ho, H. D. (1986). The weekend effect on stock returns in Singapore, Hong Kong. Journal of Business Management, 4, 31-50.

\section{(cc) $\mathrm{Br}$}

This work is licensed under a Creative Commons Attribution 3.0 License. 